\title{
Analisis Pengaruh Tenaga Kerja Asing Terhadap Pertumbuhan Ekonomi Berdampak Pada Tingkat Pengangguran di Sumatera Utara
}

\author{
Fajriawati \\ Fakultas Hukum Universitas Muhammadiyah Sumatera Utara \\ Jl. Kapten Muchtar Basri No. 3 Medan 20221 \\ e-mail: fajria.balqis@gmail.com
}

\begin{abstract}
ABSTRAK
Penelitian ini membahas tentang pengaruh tenaga kerja asing terhadap pertumbuhan ekonomi yang berdampak pada pengangguran di Sumatera Utara. Penelitian ini mengunakan data sekunder berdasarkan data kuantitatif yang mengunakan data dari BPS. Tujuan penelitian ini adalah untuk menganalisis tenaga kerja asing terhadap pertumbuhan ekonomi berdampak pada pengangguran di Sumatera Utara. Hasil dari penelitian menujukkan bahwa pengaruh tenaga asing yang bekerja di perusahaan-perusahaan di kota Medan yang menempati bermacam-macam jabatan yakni ahli asset manajemen dan berbagai macam jabatan lain. Tenaga Kerja Asing yang berada di kota medan ini berasal dari berbagai negara antara lain : China, India, Malaysia. Adapun pengaruh pertumbuhan ekonomi terhadap tenaga kerja asing adalah tingginya upah yang diterima oleh tenaga kerja asing yang membuat banyak perusahan yang melihat dan menggunakan tenaga ahli yang siap pakai yang didapat oleh para tenaga asing yang siap pakai untuk menduduki jabatan di suatu perusahaan. Kemajuan suatu daerah harus menyediakan lapangan pekerjaan yang merupakan keefektifan kesempatan angkatan kerja yang dapat ditampung oleh lapangan pekerjan, yang harus disediakan oleh pemerintah dan perusahan-perusahan sehingga dapat menampung tenaga kerja yang siap pakai untuk mendapatkan hasil yang di harapkan oleh masyarakat.
\end{abstract}

Kata Kunci: Tenaga kerja asing, Pertumbuhan Ekomomi dan Pengangguran 
This study discusses the influence of foreign workers on economic growth that has an impact on unemployment in North Sumatra. This study uses secondary data based on quantitative data using data from BPS. The purpose of this study is to analyze foreign labor against economic growth impacting unemployment in North Sumatra. The results of the study show that the influence of foreign workers working in companies in the city of Medan occupies various positions, namely asset management experts and various other positions. Foreign Workers in the city of Medan are from various countries, including: China, India, Malaysia. The influence of economic growth on foreign workers is the high wages received by foreign workers, which makes many companies that see and use experts who are ready to be obtained by foreign workers who are ready to use to occupy positions in a company. The progress of a region must provide employment which is the effectiveness of workforce opportunities that can be accommodated by employment fields, which must be provided by the government and companies so that they can accommodate workers who are ready to use the results expected by the community.

Keywords: Foreign workers, Economic Growth and unemployment 


\section{PENDAHULUAN}

Pengunaan tenaga asing telah diatur didalam pasal 37 ayat (1) peraturan Menteri Ketenagakerjaan No.35 Tahun 2015 tentang perubahan atas peraturan Menteri Ketenaga kerjaan No.16 tahun 2015 tentang cara pengunaan tenaga kerja asing ( Permenker 35/2015) selain syarat-syarat lainnya seperti yang diatur oleh pihak imigrasi. Peran pemerintah sangat diperlukan untuk menjaga agar keberadaan tenaga kerja asing tidak menjadi ancaman. Selain regulasi pokok pemerintah perlu mempertimbangkan banyak pembatasan tenaga kerja asing dari sektor kemampuan dan posisi minimal, pendidikan, batas waktu bekerja di Indonesia perlu diatur dengan ketat.

Diera globalisasi dengan adanya Masyarakat Ekonomi ASEAN (MEA), tenaga kerja asing bebas masuk ke Indonesia yang pelaksanaannya dimulai sejak tahun 2015. Keberadaan tenaga kerja asing merupakan kenyataan yang nyata, bahkan berperan penting dalam sektor perekonomian di Indonesia khususnya di Sumatera Utara. Pengaruh tenaga kerja asing dapat mempengaruhi semua aspek yang ada dimasyrakat termasuk pendidikan dan kebudayaan. Dengan adanya tenaga kerja asing menumbuhkan sikap menghargai waktu dan mau bekerja keras, terjadinya transfer pengetahuan/ahli teknologi dan membudayanya etos kerja positif kepada tenaga kerja lokal. Tenaga kerja asing yang pada gilirannya akan mendorong peluang tenaga lokal untuk menjadi pekerja berkelas internasional sehingga pada saat yang akan datang tenaga kerja lokal kita dapat bersaing dengan tenaga-tenaga kerja asing yang selama ini menempati posisi strategis didalam perusahaan. Dampak negatif yang timbul adalah terjadinya kecemburuan sosial antara masyarakat dengan tenaga kerja asing serta banyaknya pengangguran di Sumatera Utara.

\section{KAJIAN PUSTAKA \\ Kondisi Tenaga Kerja Asing}

Tenaga kerja asing adalah tiap orang bukan warga negara Indonesia yang mampu melakukan pekerjaan baik di dalam maupun di luar hubungan kerja, guna menghasilkan jasa atau barang untuk memenuhi kebutuhan masyarakat.

Melalui data BPS, jumlah tenaga kerja asing meningkat pada tiga tahun terakhir dan terus meningkat mencapai 69.025 orang atau meningkat 7,5\%. Tenaga kerja Asing di Sumatera Utara yang memiliki perkembangan positif dalam bidang industri saat ini memiliki banyak perusahaan yang mempekerjakan tenaga kerja asing untuk bekerja berikut data tenaga kerja di perusahaan di sumatera utara

Dampak ini lah yang membuat banyak tenaga kerja Indonesia banyak yng mengaggur bnyaknya tenaga kerja luar yang mengusai sumatera utara dan pemerintah harus memperhatikan dan melihat lahan pekerjaan apa yang akan diterima oleh masyarakat Sumatera Utara harus meningkatkan tenaga kerja dam mencari solusi untuk meningkatkan laju pertumbuhan ekonomi di Sumatera Utara

\section{Kondisi Tenaga Kerja Lokal di Sumatera Utara}

Sumatera Utara merupakan propinsi yang terbesar jumlahnya penduduknya di Indonesia setelah Jawa Barat dan Jawa Timur. Tingkat partisipasi angkatan kerja Sumatera Utara setiap tahun terus meningkat. Sektor yang cukup besar dalam peranannya dalam menyerap tenaga kerja adalah dibidang sektor jasa-jasa, baik jasa perorangan maupun jasa perusahaan dan jasa pemerintahan sebesar $14,96 \%$ sementara penduduk yang bekerja di sektor industri hanya sekitar $8,19 \%$. 
Selebihnya bekerja di sektor pengalian dan pertambangan, sektor listrik, gas dan air minum. Untuk bisa dibangdingkan antar wilayah atau negara maka konsep ketenagakerjaan yang digunakan adalah konsep labour force framework sesuai yang telah direkomendasikan. Penduduk di bagi menjadi dua kelompok besar yaitu kelompok usia kerja dan bukan usia kerja. Dalam memberikan batasan umur pada usia kerja, menggunakan batas usia kerja 15 tahun dan tanpa batas atas usia kerja.

Meningkatnya laju pertumbuhan ekonomi yang dapat melihat keberhasilan yang ada pada daerah untuk meningkatkan tarap hidup masyarakat di daerah tersebut. Adapun pengaruh pertumbuhan ekonomi terhadap tenaga kerja asing tingginya upah yang diterima oleh tenaga kerja asing yang membuat banyak perusahan yang melihat dan mengunakan tenaga ahli yang siap pakai yang terdapat oleh para tenaga asing yang siap pakai untuk menduduki di suatu perusahaan. Kemajuan suatu daerah harus menyediakan lapangan pekerjaan yang merupakan keefektifan kesempatan angkatan kerja yang tersedia dapat ditampung oleh lapangan pekerjan yang harus disediakan oleh pemerintah dan perusahanperusahan yang dapat menampung tenaga kerja yang siap pakai untuk mendapatkan hasil yang di harapkan oleh masyarakat .

Pertumbuhan ekonomi yang meningkat tidak dibarengi dengan peningkatan jumlah lapangan pekerjaan yang tercipta sehingga mengakibatkan masih tingginya angka pengangguran yang berujung dengan tingkat kemiskinan. Menurut Mankiw ( 2006: 154), penganguran adalah masalah makro ekonomi yang mempengaruhi manusia secara langsung dan merupakan masalah yang paling berat. Bagi kebanyakan orang kehilangan pekerjaan berarti penurunan standart kehidupan dan tekanan psikologis. Jadi tidaklah mengejutkan jika penganguran menjadi topik yang sering dibicarakan dalam perdebatan politik dan para politisi sering mengklam bahwa kebijakan yang mereka tawarkan adalah membantu menciptakan lapangan pekerjaan.

Pembangunan ekonomi suatu daerah pada dasarnya merupakan interaksi dari berapa kelompok sumber daya manusia, sumber daya alam dan modal serta teknologi. Pembangunan ekonomi merupakan suatu upaya mencapai pertumbuhan dan kesejahteraan sosial yaitu kegiatan yang dilakukan suatu negara untuk mengembangkan kegiatan ekonomi dan taraf hidup masyarakat.

Pertumbuhan ekonomi adalah perkembangan kegiatan dalam perekonomian yang menyebabkan barang dan jasa yang diproduksi dalam masyarakat bertambah (Sukirno, 2006: 9). Negara perlu mencapai pertumbuhan ekonomi tinggi untuk menaikkan tingkat kemakmuran rakyat. Kemakmuran rakyat terlibat ketika kesediaan kesempatan kerja selalu bertambah dan rakyat yang merupakan tenaga kerja mendapatkan pekerjaan dari dari kesempatan kerja tersebut. Pertumbuhan ekonomi sebagai suatu proses terhadap kenaikan produktivitas dari faktor-faktor produksi yang menghasilkan output dan dinyatakan dalam pendapatan nasional.

Pertumbuhan ekonomi mempunyai tiga komponen antara lain: pertama, pertumbuhan ekonomi suatu bangsa terlihat dari meningkatnya secara terus-menerus persediaan barang, kedua, teknologi maju adalah faktor dalam pertumbuhan ekonomi yang menentukan derajat pertumbuhan kemampuan dalam penyedian aneka macam barang kepada penduduk dan ketiga, penggunaan teknologi secara luas dan efisien memerlukan adanya suatu penyelesaian di bidang kelembagaan dan ideologi sehingga inovasi yang dihasilkan oleh ilmu pengetahuan. 


\section{Published December 2018}

\section{EKONOMIKAWAN : Jurnal Ilmu Ekonomi dan Studi Pembangunan}

ISSN : 1693-7600 (Print), ISSN : 2598-0157 (Online), http://jurnal.umsu.ac.id/index.php/ekawan

Adapun ciri-ciri pertumbuhan ekonomi antara lain :

1. Laju pertumbuhan penduduk dan produk perkapita

Pertumbuhan modern yang sebagaimana terungkap dari pengalaman negara maju sejak akhir abad ke-18 atau awal abad ke-19, ditandai dengan laju kenaikan produk perkapita yang tinggal dibarengi dengan laju pertumbuhan penduduk yang cepat, laju kenaikan yang luar biasa itu paling sedikit sebesar lima kali untuk penduduk dan paling sedikit sepuluh kali untuk produksi.

2. Peningkatan produktivitas

Pertumbuhan ekonomi modern terlibat dari semakin meningkatnya laju produk perkapita utama sebagai adanya perbaikan kualitas input yang meningkatkan suatu efisien atau produktifitas perunit input. Semakin besarnya masukan sumber tenaga kerja dan modal atau semakin besarnya masukan sumber tenaga kerja dan modal atau semakin meningkatnya efisiensi atau kedua-duanya. Kenaikan efiesensi berarti penggunaan output yang lebih besar untuk setiap unit input.

3. Laju pertumbuhan struktural yang tinggi

Perubahan stuktur dalam pertumbuhaan ekonomi modern mencakup peralihan dari kegiatan pertanian ke non pertanian dari industri ke jasa, perubahan dalam skala unit-unit produktif dan peralihan dari perusahaan perseorangan menjadi perusahaan terhadap hukum serta perubahan status kerja buruh.

4. Urbanisasi

Pertumbuhan ekonomi modern ditandai pula dengan semakin banyak penduduk negra maju yang berpindah dari daerah pedesaan ke daerah perkotaan. Inilah yang disebut urbanisasi. Urbanisasi pada umumnya adalah produk industrialisasi. Skala ekonomi yang muncul dalam usaha non agraris sebagai hasil perubahan teknologi mengakibatkan perpindahaan tenaga kerja dan penduduk secara besar-besaran dari pedesaan ke perkotaan. Karena sarana teknisi transportasi, komunikasi dan organisasi berkembang menjadi lebih efektif, maka terjadinya penyebaran unit-unit skala optimum. Proses ini mempengaruhi pengelompokan penduduk berdasarkan status sosial dan ekonomi serta mengubah pola dasar peri kehidupan.

5. Ekspansi negara maju

Pertumbuhan negara maju kebanyakan tidak sama. Pada berapa bangsa, pertumbuhan ekonomi modern terjadi lebih awal dari pada bangsa yang lain.

6. Arus barang, modal dan orang asing antar bangsa

Arus barang, modal dan orang antar bngsa kian meningkat sejak kuartal kedua abad ke-19 sampai perang dunia 1 tetapi mulai mundur pada perang dunia 1 tetapi mulai mundur pada perang dunia 1 dan berlanjut sampai akhir perang ke II demikian sejak awal tahun lima puluh terjadinya peningkatan dalam arus barang, modal dan antar bangsa. 


\section{Published December 2018}

EKONOMIKAWAN : Jurnal Ilmu Ekonomi dan Studi Pembangunan

ISSN : 1693-7600 (Print), ISSN : 2598-0157 (Online), http://jurnal.umsu.ac.id/index.php/ekawan

\section{METODE}

Penelitian ini adalah penelitian deskriptif kuantitatif yang bertujuan untuk menganalisis pengaruh tenaga asing terhadap pertumbuhan ekonomi yang berdampak pada penganguran di Sumatera Utara. Penelitian ini menggunakan data skunder yang diambil dari Dinas Ketenagakerjaan dan Badan Pusat Stastitik Sumatera Utara dalam waktu 3 tahun untuk mengetahui perkembangan pertumbuhan ekonomi yang menggunakan tenaga kerja asing yang berdampak pada tenaga kerja Indonesia yang banyak menganggur yang tidak mendapat pekerjaan.

\section{PEMBAHASAN}

Masuknya tenaga kerja asing lebih banyak pengaruh negatifnya terhadap suatu daerah dengan adanya peningkatan pertumbuhan ekonomi yang dikuasai oleh tenaga kerja asing. Pemerintah harus mengambil tindakan mana yang harus kita lihat perkembangannya di suatu perekonomian yang dapat dipersempit dan banyak masyarakat Sumatera Utara yang menganggur karena banyaknya tenaga asing yang masuk ke Sumatera Utara. Dan daya beli masyarakat Indonesia harus ditingkatkan yang akan mendukung perekonomian.

Tabel 1

Tenaga Kerja Asing yang Bekerja di Perusahaan

di Sumatera Utara

Pada tahun 2014

\begin{tabular}{|l|c|}
\hline \multicolumn{1}{|c|}{ Nama Perusahaan } & Jumlah Tenaga Kerja Asing \\
\hline PT.Unilever & 125 orang \\
\hline PT.Danone & 67 orang \\
\hline PT.CIMB Niaga & 23 orang \\
\hline PT.Nestle & 18 orang \\
\hline \multicolumn{1}{|c|}{ Total } & 233 orang \\
\hline
\end{tabular}

Sumber : Dinas Tenaga kerja kota Medan, 2017

Berdasarkan tabel diatas, jumlah tenaga kerja asing yang bekerja di perusahaanperusahaan di Kota Medan yaitu 233 orang dimana jabatan yang ditempati bermacammacam yakni ahli asset manajemen dan berbagai macam jabatan lain. Tenaga Kerja Asing yang berada di kota Medan ini berasal dari berbagai negara antara lain : China, India, Malaysia.

Secara kuantitatif penduduk usia kerja yang berpendidikan maksimal SD pada 8.38 $\%$ yang berpendidikan SMP 24,24\% dan SMA 37,49 dan universitas 7,53 yang berpendidikan diploma dan universitas juga mengalami persentase kenaikan yang singnifikan pada tahun 2014.

Peningkatan kualitas pendidikan ini disebabkan berapa hal diantaranya pembangunan ekonomi selama ini pada tingkat tertentu berhasil meningkatkan pendapatan masyarakat menjadi lebih mampu membiayai pendidikan formal, mengakomodasikan makanan bergizi yang membantu kualitas tenaga kerja. 
Published December 2018

EKONOMIKAWAN : Jurnal Ilmu Ekonomi dan Studi Pembangunan

ISSN : 1693-7600 (Print), ISSN : 2598-0157 (Online), http://jurnal.umsu.ac.id/index.php/ekawan

Tabel 2

Jumlah Pencari Kerja Terdaftar Menurut Pendidikan yang Ditamatkan Menurut jenis kelamin Tahun $2014(\%)$

\begin{tabular}{|c|l|c|c|c|}
\hline No & Tingkat Pendidikan & Laki-laki & Perempuan & Laki+ perempuan \\
\hline 1 & Tidak/Belum Pernah Sekolah & 1.08 & 2,55 & 1.65 \\
\hline 2 & Tidak / Belum Tamat SD & 8.38 & 12,14 & 9,84 \\
\hline 3 & Tamat SD & 21,29 & 21,98 & 21,56 \\
\hline 4. & Tamat SMTP & 24,24 & 18,98 & 22,2 \\
\hline 5. & Tamatan SMTA & 37.49 & 32.32 & 35,48 \\
\hline 6. & Diploma I/11/111/1V, Universitas & 7,53 & 12.02 & 9.27 \\
\hline & Jumlah & 100 & 100 & 100 \\
\hline
\end{tabular}

Sumber : BPS, 2017.

Para pendatang baru di pasar kerja yang jumlahnya tidak sedikit akan mendatangkan masalah baru jika lapangan pekerjaan yang disediakan tidak mampu menyerap mereka semua. Mereka sebagai penyebab meningkatnya partisipasi angkatan kerja, namun bila mereka tidak bekerja maka mereka akan masuk kedalam kelompok para pencari kerja atau penganguran.

Dalam proses mempermudahkan perizinan yang dilakukan oleh pemerintah pusat sudah cukup baik sementara untuk otonomi daerah sangat lambat ini harus segera dirubah perizinannya, harus singkat tapi tanpa melanggar aturan yang ada pada pihak pemerintahan. Semakin banyak membuka lapangan pekerjaan menurunkan penganguran. Industri tersebut merupakan sektor yang dimiliki multipliner effect yang paling besar untuk mendongkrak pertumbuhan ekonomi. Data BPS Sumatera Utara juga mencatat jumlah penduduk yang bekerja berdasarkan lapangan pekerjaan utama juga mengalami penurunan pada industri menjadi $7,55 \%$ atau 450 orang dari $7,84 \%$ atau 461 orang. Adapun sektor yang memiliki peningkatan jumlah tenaga kerja yakni perdagangan, jasa kemasyarakatan, sosial, dan perorangan.

Tabel 3

Data Pengangguran Dampak dari Tenaga Kerja Asing di Sumatera Utara Tahun 2014-2016

\begin{tabular}{|l|c|c|c|}
\hline \multicolumn{1}{|c|}{ Kab/ Kota } & 2014 & 2015 & 2016 \\
\hline Medan & 15.147 & 15.718 & 16.210 \\
\hline Pematang Siantar & 6.212 & 6.812 & 6.611 \\
\hline Tebing Tinggi & 7.271 & 8.121 & 7.281 \\
\hline Binjai & 8.710 & 7.125 & 7.811 \\
\hline
\end{tabular}

Sumber : BPS, 2017.

Data pengangguran dari tahun 2014 sampai 2016 semakin meningkat dan dapat dilihat pada tabel 3 dengan jelas adanya pengangguran yang semakin bertambah di kota Medan, Pematang Siantar, Tebing Tinggi dan Binjai. Dampak yang sangat terasa dengan adanya tenaga kerja asing yang bekerja di Sumatera Utara akan menambah pengangguran bagi para penduduk yang ada di Sumatera Utara . 


\section{Published December 2018}

\section{EKONOMIKAWAN : Jurnal Ilmu Ekonomi dan Studi Pembangunan}

ISSN : 1693-7600 (Print), ISSN : 2598-0157 (Online), http://jurnal.umsu.ac.id/index.php/ekawan

Kebijakan pemerintah untuk menurunkan tingkat pengangguran dengan mendongkrak pertumbuhan ekonomi Sumatera Utara khususnya sektor industri yang berdampak pada tingkat kesempatan kerja yang ada. Pemerintah akan memperkirakan dalam 5 tahun ke depan perekonomian paling tidak secara nasional ada tambahan 3 juta pekerjaan untuk tenaga kerja di Sumatera Utara untuk mendapat pekerjaan yang harus di perhitungkan dan diperhatikan oleh pemerintah untuk membuka lapangan pekerjaan yang dapat mengningkatkan taraf perekonomian yang ada di Sumatera Utara dan tidak kalah saing dengan perusahaan asing yang banyak mengusai perusahaan yang ada di Sumatera Utara.

\section{SIMPULAN}

Perekonomian provinsi Sumatera Utara terus menujukkan perbaikan dan peningkatan dalam pertumbuhan ekonomi. Pertumbuhan ini dapat diharapkan akan berdampak pada penyerapan tenaga kerja yang besar sehingga jumlah penganguran dan jumlah penduduk miskin di provinsi sumatera utara berkurang. Pertumbuhan sektor-sektor yang memberikan kontribusi yang besar dan dapat diharapkan akan membuka kesempatan baru yang lebih banyak terutama di sektor industri dan pertanian. Kebijakan pemerintah daerah dalam hal galian diarahkan untuk optimalisasi pemanfataan lahan dengan pemberdayaan masyarakat lokal agar terbuka kesempatan kerja bagi masyrakat lokal. Untuk menghindari kerusakan lingkungan yang disebabkan oleh kegiatan yang dapat dicapai apabila didukung oleh strategi pemberdayaan potensi peningkatan pemahaman tentang ilmu pengetahuan dan teknologi masyrakat.

\section{DAFTAR PUSTAKA}

Abdul Hakim. 2009. Dasar Hukum Ketenaga Kerjaan Indonesia. Citra Aditya Bakti, Bandung.

Stanislaus Riyanta. 2016. Ancaman Tenaga Asing Di Indonesia, Utama News.

Abdul Hamid Al-Mansury, mahasiswa STIE Tazkia Sentul City Bogor, Kabid PA HMI Cabang Bogor ( selasa, 08 Mei 2018: 11:07)

Ady Soejoto, 2011. Pertumbuhan Ekonomi dan Penganguran Terhadap Kemiskinan di Jawa Timur.

Badan Pusat Statistik. 2014. Tingkat Pengangguran Terbuka Sumatera Utara, Badan Pusat Statistik, Medan.

Badan Pusat Statistik. 2015. Tingkat Ketenagakerjaan Sumatera Utara. Badan Pusat Statistik, Medan.

Badan Pusat Statistik. 2014. Tingkat Tenaga Kerja Asing Sumatera Utara. Badan Pusat Statistik, Medan.

Dinas Tenaga kerja dan transmigrasi Provinsi Sumatera Utara, Profil Ketenagakerjaan Tahun 2014-2016.

Ditjen Pembinaan Pengawasan Ketenagakerjaan Depnakertrans RI. 2009. Profil Data dan informasi pengawasan Ketenagakerjaan Tahun 2013, Jakarta.

Mankiw,G. 2006. Makro ekonomi. Erlangga, Jakarta.

Todaro, Michael P. 2011. Pembngunan Ekonomi Jilid pertama edisi kesebelas. Erlangga, Jakarta. 